\title{
PENGOLAHAN IKAN CAKALANG ASAP (Katsuwonus pelamis) DENGAN PENILAIAN ORGANOLEPTIK
}

\author{
Azis Husen 1 \\ ${ }^{1}$ Program Studi Teknologi Hasil Perikanan, Fakultas Pertanian, Universitas Muhammadiyah Maluku \\ Utara, Jln. K.H. Ahmad Dahlan,TernateTelp/Fax : 0921-326136 \\ E-mail : azishusen50@yahoo.com \\ Manuscript received: 09-09-2018, Revision accepted: 05-11-2018
}

\begin{abstract}
Abstrak
Tujuan utama penelitian ini adalah untuk mendapatkan asap yang dihasilkan dari pembakaran kayu, terdiri dari uap dan partikel padatan yang berukuran sangat kecil agar penempelan dan pelarutan asap berjalan efektif sehingga memberikan rasa dan aroma yang khas pada ikan. Hasil pembakran dari tiga bahan bakar, yakni kayu mangrove, sabut kelapa, dan tempurung kelapa ternyata menghasilkan aroma dan rasa yang berbeda pada produk dan warnanya menjadi keemasan atau kecoklatan. Proses pengasapan yang digunakan adalah media drum tertutup, dan jumlah ikan yang digunakan sebanyak 16 ekor. Tujuan penelitian ini adalah untuk mengetahui pengolahan ikan asap cakalang (Katsuwonus pelamis) dengan analisis organoleptik. Ikan diasapi dengan menggunakan suhu panas $88-99{ }^{\circ} \mathrm{C}$ dengan pengasapan kontrol sehingga hasil pengasapan ikan merata. Pengujian organoleptik sebanyak 26 panelis terhadap produk pengasapan ikan cakalang. Pengujian terhadap variabel penampakan ikan dengan nilai tertinggi rata-rata 7.76, sabut kelapa dengan nilai rata-rata 6.22, dan tempurung kelapa 6 . Hasil pengujian ikan cakalang asap dengan menggunakan kayu mangrove, tampurung kelapa, sabut kelapa mendapatkan nilai sangat berbeda nyata pada variabel penampakan, rasa warna, tekstur, dan aroma.
\end{abstract}

Kata kunci: Pengasapan ikan cakalang dengan penilain organoleptik

\section{PENDAHULUAN}

Sektor perikanan dan kelautan di Maluku Utara khususnya di Kota Ternate yang memiliki prospek yang cerah untuk dikembangkan menjadi suatu kegiatan ekonomi yang tangguh sinergi dan berkelanjutan, hal ini didukung oleh potensi sumber daya perikanan yang relatif besar yang harus diberkembang lebih besar lagi. (BPS Halmahera Utara, 2009).

Ikan asap merupakan salah satu hasil olahan tradisional yang hampir semua jenis ikan dapat digunakan sebagai bahan baku pengolahan pengasapan dengan memanfatkan kombinasi perlakuan dan pemberian senyawa kimia alami dari hasil pembakaran bahan bakar alami.

Pengasapan ikan berubah menjadi kuning emas sampai kecoklatan, warna yang dihasilkan adalah reaksi kimia melalui proses pengasapan ikan tergantung suhu dan lingkungan sehingga daging ikan yang diasapi warnanya merata (Adawyah, 2007).

Pengasapan merupakan cara pengolahan dengan memanfaatkan kombinasi perlakuan pengeringan dan pemberian senyawa kimia alami dari hasil pembakaran bahan bakar alami yang mempengaruhi proses pengasapan, diantaranya suhu pengasapan. Pengasapan sebaiknya mengunakan suhu yang tinggi karena ikan yang diasapi menghasilkan perubahan 


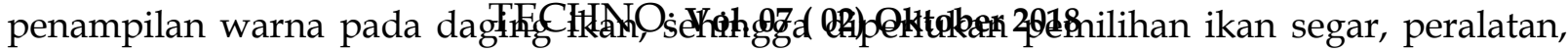
dan bahan asap-asap seperti bahan bakar kayu (Moeljanto, 1992).

Ikan tidak akan bisa di pertahankan apabila penanganan dan pengolahan tidak cepat dilakukan, oleh sebab itu setiap pengolahan hasil perikanan yang memegang peranan penting adalah mutu. Mutu daging ikan asap yang baik adalah memiliki harga jual yang memuaskan. Sebaliknya bila ikan sudah mengalami kerendahan mutu, maka hasil yang diperoleh tidak sesuai dengan yang diharapkan. Berdasarkan uraian diatas maka tujuan penelitian ini adalah untuk mengetahui pengolahan ikan asap cakalang (Katsuwonus pelamis) dengan analisis organoleptik.

\section{METODE PENELITIAN}

Penelitian ini dilaksanakan pada bulan September bertempat di Laboratorium Teknologi Hasil Perikanan Universitas Muhammadiyah Maluku Utara di lanjutkan analisis organoleptik dengan jumlah panalis 26 0rang untuk mengetahui penempakan, rasa, warna, tekstur dan aroma ikan cakalang asap dan analisis statistik.

Tempat dan wadah yang terbuat dari drum, panggang besi, baskom, penjepitan, papan pemotong, pisau, colbox, termometer, Baskom, sarung tangan timbangan, gelas pengukur dan lembaran uji organoleptik (scoor sheet), serta alat tulis menulis. Ikan yang digunakan ikan cakalang, sedangakan bahan bakar yang digunakan kayu mangrove, tampurung kelapa, sabut kelapa minyak tanah dan minyak kelapa..

Prosedur penelitian ikan cakalang asap antara meliputi, tahap persiapan, tahap pencucian, daging ikan cakalang (Katsuwonus pelamis) disiangi kemudian dicuci bersih, tahap penerisan daging dengan cara berdiri tujuannya untuk mengurangi air, tahap pengasapan dipisahkan sesuai jenis ukuran ikan, proses pengasapan ikan dengan suhu panas selanjutnya ikan yang diasapi dibalik dioleskan dengan minyak kelapa dan kemudian ikan diasapi ulang sampai matang.

\section{HASIL DAN PEMBAHASAN}

\section{Pengasapan Ikan Caklang}

Proses pengolahan pengasapan ikan asap dengan jumlah ikan yang dipakai adalah 18 ekor masing-masing pengasapan yang di gunakan adalah 6 ekor ikan dengan tiga perlakuan yang dipakai dalam pengasapan dengan memakan waktu 2 jam selama pengasapan keseluruhan waktu total adalah 6 jam. Pengasapan ikan yang gunakan adalah pengasapan suhu panas dengan menggunakan bahan bakar sabut kelapa, tempurung kelapa dan kayu mangrove proses pengasapan ikan asap dilakukan secara sederhana dengan menggunakan drum. Ikan yang diasapai dengan suhu $88^{\circ} \mathrm{C}-99^{\circ} \mathrm{C}$ dan lama penyimpanan 1 hari tujannya agar ikan cepat dingin selanjutnya ikan cakalang asap dianalisis organoleptik.

Pengasapan dengan menggunakan media drum yang dimana daging ikan yang diasapi di dalam media tertutup agar udara dari luar tidak masuk kedalam drum pengasapan sehingga daging ikan yang diasapi matang secara merata dan daya awet daging ikan lebih tinggi di bandingkan dengan cara pengasapan mengunakan ruangan atau media lain. Proses pengasapan ikan cakalang yang diasapi didalam drum pengasapan stengah matang setelah 1 


\section{Husen, Aziz. Pengasapan ikan cakalang dengan penilain organoleptik.}

jam dibalik dan dioleskan dengan minyak kelapa agar daging ikan asap mempunyai aroma, rasa, tekstur, penampakan, warna yang cerah setelah itu dimasukan kembali didalam drum pengasapan selama 1 jam kembali daging ikan asap yang diasapi sesudah matang secara merata diangkat dan dikeluarkan dari media pengasapan, untuk menentukan nilai mutu dan berapa lama penyimpanan pada ikan asap yang dihasilkan mempunyai rasa daging yang enak.

Pengujian organoleptik sebanyak 26 panalis untuk memperoleh rasa ikan yang diinginkan nilai mutu ikan cakalang asap pada pertama diteliti masih sempurna dan normal artinya ikan asap cakalang masih dapat diterima oleh panalis untuk penampakan keseluruhan ikan cakalang masih utuh, bersih, rapi dan menarik sementara untuk bau masih netral.

\section{Penampakan}

Hasil penelitian mendapatkan tingkat penerimaan terhadap penampakan daging cakalang asap dari tiga bahan bakar yang digunakan yaitu kayu mangrove dengan nilai 1.81, tempurung kelapa 1.51, dan sabut kelapa 1.09 dengan demikian nilai penampakan untuk daging ikan cakalang lebih tinggi dibandingakan tempurung kelapa dan sabut kelapa karena kadar selulosa lebih rendah dan seratnya kurang sehingga parameter penampakan yang dinilai oleh panelis lebih rendah. Nilai penampakan ikan asap merupakan keadaan keseluruhan daging ikan cakalang secara visual yang menyebabkan panelis tertarik dan suka pada produk ikan cakalang asap yang dihasilkan kerena mempunyai penampakan yang cerah.

\section{Rasa}

Rasa merupakan salah satu faktor penentu tingkat kesukaan panelis terhadap produk pangan. Hasil analissi organoleptik ikan cakalang asap untuk tempurung kelapa dengan nilai 1.77, mangrove 1.6, sabut kelapa dengan menilai 0,78. Kayu mangrove dan sabut kelapa mempunyai karbon arang pembakaran kurang banyak sehingga bahan bakar kurang berjalan efektik disebkan oleh faktor udara yang masuk didalam drum pengasapan sehinga rasa yang banyak diminati oleh panelis dengan niali tertinggi adalah tempurung kelapa. Rasa merupakan sifat bahan makanan dan juga mekanisme reseptor orang yang makan makanan. Rasa mencakup perasaan yang dihasilkan oleh barang yang dimasukan ke mulut dirasakan susunan senyawa dalam makanan yang mengandung rasa atau bau, dan juga atraksi senyawa-senyawa reseptor alat indra rasa dan bau setelah terjadi ataraksi, organ menghasilkan sinyal yang langsung dihantakan ke sistem saraf pusat dengan demikian menciptakan apa yang kita kenal sebagai rasa yang sesungguhnya, manis, pahit, masam, dan asin kepekaan terhadap rasa terdapat pada kuncup rasa lidah bahan yang menghasilkan dengan perasaan tersebut.

\section{Warna}

Hasil analisis organoleptik warna daging ikan cakalng asap untuk kayu mangrove dengan nilai 1.43, tempurung kelapa 1.29 dan sabut kelapa 1.18. Hasil menunjukan bahwa kayu mangrove jumlah nilainya lebih tertinggi dibandingkan tempurung kelapa dan sabut kelapa. Menurut Moeljanto, (1992). Mangrove di kategorikan sebagai kayu keras karena mempunyai halophyte atau toleransi yang tinggi terhadap tingkat keasinan kadar garam, sehingga warna 


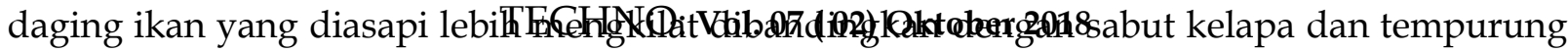
kelapa yang kadungan garamnya tidak ada.

\section{Tekstur}

Tekstur dapat berupa kekerasan dan kerenyahan dalam produk yang dihasilkan sehingga dari hasil analissi organoleptik mendapatkan nilai kayu mangrove 1.68, sabut kelapa 14.4 dan tempurung kelapa 0,87 dengan demikian nilai tertinggi untuk tekstur ikan cakalang asap adalah kayu mangrove. Bahan bakar tempurung kelapa dan sabut kelapa karena asap yang dihasilkan kurang merata dikarenakan kelembaban udara, dan suhu panasnya rendah sehingga proses penempelan senyawa pertikel dari tempurung dan sabut kelapa kurang berjalan efektif dibandingkan dengan kayu mangrove yang proses pengasapanya berjalan efektif karena bahan bakar kayunya lunak sehingga tekstur pengasapan yang dihasilkan sempurna dan elastis.

\section{Aroma}

Hasil analisis organoleptik untuk aroma ikan cakalang asap dengan menggunakan bahan bakar kayu mangrove mendapatkan nilai 1.24, sabut kelapa 1.16 dan tempurung dengan nilai 0.98, dengan demikian nilai tertinggi adalah kayu mangrove. Menurut Timan, (1981). Sabut kelapa dan tampurung kelapa kurang maksimal disebkan oleh udara dan asap yang berjalan kurang efektik sehingga hasil dari pembakaran kurang menempel pada daging ikan yang diasapi dan tidak berjalan sesuai dengan diharapkan sehingga aromanya kurang harum dibandingkan dengan kayu mangrove masih mempunyai kandungan garam didalam dan zat pewarna yang tinggi sehingga penempelan asap pada daging ikan berjalan secara merata maka aroma ikan yang diasapnya lebih harum (Timan, 1981).

\section{SIMPULAN DAN SARAN}

\section{Kesimpulan}

Hasil penelitian pengasapan ikan masih dapat diterima oleh panalis setelah hari pertama untuk warna, rasa, aroma, penampakan dan tekstur daging ikan cakalang masih utuh, bersih, rapi dan menarik sementara untuk bau masih netral. Hasil analisis pengasapan ikan cakalang menggunakan organoleptik dengan bahan bakar yaitu mangrove memiliki nilai rata-rata tertinggi sebesar 7.76 pada semua parameter uji organoleptik terhadap warna, rasa, aroma, penampakan dan tekstur. Kedua sabut kelapa dengan nilai rata-rata 6.22 dan yang ketiga adalah tempurung kelapa dengan nilai rata-rata 6.0 dengan demikian nilainya berbeda nyata

\section{Saran}

Berdasarkan hasil penelitian ini maka penulis menyarankan bahwa :

1. Untuk menghasilkan pengasapan ikan yang bermutu perlu dilakukan penanganan secara baik dan cepat sesuai dengan standar Nasional Indonesia (SNI) dan memperhatikan lingkungan sekitar.

2. Perlu dilakukan pengujian lanjutan yaitu untuk mengetahui lama penyimpanan, analisis bakteri dan kadar air pada daging ikan cakalang asap.

\section{Ucapan Terima Kasih}




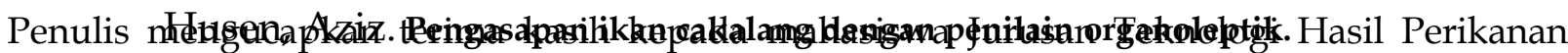
dan Laboratorium Teknologi Hasil Perikanan Universitas Muhammadiyah Maluku Utara yang telah membantu fasilitas sehingga dapat terselesainya penelitian ini.

DAFTAR PUSTAKA

Badan Pusat Statistik Provinsi Maluku Utara. 2009. Maluku Utara Dalam Angka 2009.

Deman, M John. 1997. Kimia Makanan Bandung: ITB.

Rabiatul Adawyah. 2006. Pengolahan dan Pengawetan Ikan, Jakarta.

Timan D. 1981 Wood Combution, Pengambilan Asap Cair Secara Destilasi Kering pada Proses Pembuatan Karbon Aktif dari Tempurung Kelapa (Skripsi), FMIPA UGM, Yogyakarta.

Maeljanto 1992. Pengawetan dan Pengolahan Hasil Perikanan. Penerbit. Penebar Soadaya, Jakarta. 